\title{
DECODING POETIC COLOURING OF DETECTIVE STORIES: PRINCIPLES OF READING
}

\author{
Babelyuk O. A.
}

\section{INTRODUCTION}

Style in literature might be defined as a special way a definite author uses different language units in his writing. According to Encyclopedia Britannica it is a technique that an individual author uses while producing a text. It varies from author to author, and depends upon one's syntax, word choice, and narration. It can also be described as a "voice" that readers listen to when they read a work of this writer. ${ }^{1}$ One may distinguish four types of style: expository or argumentative, descriptive, persuasive and narrative.

On the other hand, style is, according to N. Chomsky's nomenclature, the tension between deep structure and surface structure of the text. It can therefore be said that it is a relation between what the text means and what syntactic constructions mean. So, style is understood as a way of expressing a specific content.

Authors often wonder how to achieve a good style of writing and whether it is the same as the author's voice. The novelty here is that the essence of a good style is fluency of the language, correct use of words and grammatical rules, and the ease with which the reader can follow the story. For some time, among the creators of high literature, there was a manner for applying style far removed from the colloquial speech. In the criminal literature this could be a major obstacle in the reception of reading. Complex syntax, sophisticated descriptions, hermetic vocabulary and other author's performances make it virtually impossible to create a story with the pace that readers expect.

Definitions of a good writing style were created in all languages and in every epoch. Seneca believed that: Style has no protracted principles; it changes under the influence of use, it does not remain the same for a moment ${ }^{2}$. Aristotle claimed that: The basis of good style is linguistic correctness ${ }^{3}$.

In our century, E. Waugh proposed three goals in order to work out a good style: clarity, which should be developed, elegance to which one should strive and a recognizable voice about which one can at least pray ${ }^{4}$.

\footnotetext{
${ }^{1}$ Style in literature. URL: www.britannica.com /style in literature (retrieved Feb. 20, 2019)

${ }^{2}$ Definition of style. URL: www.thelatinlibrary.com (retrieved Feb. 20, 2019)

${ }^{3}$ Definition of style. URL: www.thelatinlibrary.com (retrieved Feb. 20, 2019)

${ }^{4}$ Evelyn Waugh. URL: www.biography.com/people/evelyn-waugh (retrieved Feb. 20, 2019)
} 
The book of C. Connolly Enemies of Promise, published in 1938, contains still current intellectualization about style. It was written at a time when the attitude of writers was changing to the style of what Connolly did not approve of. Writers had divided two types of language: spoken language and official language, which was carefully constructed and used in literary writing. When several writers including E.M. Forster broke this convention and decided to write novels in colloquial spoken language there were objections. Critics complained that literature became similar to journalism. They were afraid that literary language would stop matter and it could be reached the moment in which the reader would not have any contact with something like a good style at all.

The novelty of style issue is that it does not impose too much what is admired as transparent. In popular literature, where fast pace is important, such style is an asset because it does not make it difficult for the reader to understand the content of the book. The author makes a conscious decision and deprives his language of both difficulties and literary ornamentation.

Authors usually believe that what comes naturally is natural. For example, Highsmith and Simenon prefer transparent and unadorned style. That kind of style has a hidden value: its plainness contrasts with complex intrigue thus may mislead the reader. It is worth citing an extract from G. Simenon's Maigret Bides His Time:

The day had started like a memory of childhood, dazzling and delectable. For no reason, because life was wonderful, Maigret's eyes laughed as he had his breakfast, and the eyes of Madame Maigret, who was sitting opposite him, were just as merry.

The windows of the flat were wide open, letting in the smells from outside, the familiar noises from Boulevard Richard-Lenoir, and the air, already warm, was quivering; a fine vapor filtered the sunrays and made them almost tangible $e^{5}$.

In above passage a plain writers' style might be clearly observed. Simenon gave a simple description how Inspector Maigret had started his working day but after that the author also depicted the weather so the reader due to some stylistic devices might almost feel it.

The style of another detective story's writer A. Christie might be also characterized as interesting but it differs from Simenon's. The author had a tendency to start with unexpected events and unforeseen turns of the action. In Murder of Roger Ackroyd she begun with the description of Mrs. Ferras's death but without presenting why she died:

\footnotetext{
5 Maigret And The Death Of A Harbor Master. URL: www.archive.org/details/MaigretAndTheDeath OfAHarborMasterMarinerBooks198 (retrieved Feb. 22, 2019)
} 
Mrs. Ferrars died on the night of the $16^{\text {th }} 17^{\text {th }}$ September - a Thursday. I was sent for at eight o'clock on the morning of Friday the $17^{\text {th }}$. There was nothing to be done. She had been dead some hours. It was just a few minutes after nine when I reached home once more. I opened the front door with my latchkey, and purposely delayed a few moments in the hall, hanging up my hat and the light overcoat that I had deemed a wise precaution against the chill of an early autumn morning. To tell the truth, I was considerably upset and worried. I am not going to pretend that at that moment I foresaw the events of the next few weeks. I emphatically did not do so ${ }^{6}$.

Nevertheless the style of A. Christie might be also characterized as repetitive because for e.g. in Murder in Mesopotamia, Hercule Poirot's Christmas, Hickory Dickory Dock, The Labours of Hercules there is at the beginning a representation of characters, a definite situation/atmosphere described, then the murder, then Hercule Poirot arrived, investigates all possible clues, interrogated all potential "guilty" characters, and finally presented his amazing intelligence to resolve the matter.

To achieve a good style A. Christie regularly was looking for the inspiration by studying people around, however a murder mystery genre stunted her writing process, especially because it was difficult to put reality into fictional events. To overcome that obstacle she developed many characters from the very beginning. She had a manner to observe strangers and then used their traits to excogitate style of mystery. A. Christie was also adept at connecting subject matter with delicate story development, creative structure and psychology. That could be observed in Curtain, in a brilliant ending: Manuscript written by Hercule Poirot:

'By taking Norton's life, I have saved other lives - innocent lives. But still I do not know ... It is perhaps right that I should not know. I have always been so sure - too sure ...

'But now I am very humble and I say like a little child "I do not know ...'

'Goodbye, cher ami. I have moved the amyl nitrate ampoules away from beside my bed. I prefer to leave myself in the hands of the bon Dieu. May his punishment, or his mercy, be swift!

'We shall not hunt together again, my friend. Our first hunt was here - and our last ...

'They were good days.

'Yes, they have been good days ...' (End of Hercule Poirot's manuscript.) Final note by Captain Arthur Hastings: I have finished reading ... I cannot believe it all yet ... But he is right. I should have

\footnotetext{
${ }^{6}$ The Murder of Roger Ackroyd. URL: www.harpercollins.com/the-murder-of-roger-ackroyd (retrieved Feb. 22, 2019)
} 
known. I should have known when I saw the bullet hole so symmetrically in the middle of the forehead.

Queer - it's just come to me - the thought in the back of my mind that morning.

The mark on Norton's forehead - it was like the brand of Cain ...

Summarizing it might be claimed that a writing style of authors of detective stories depends on their language skills, correctness in using grammatical forms and structures, and the writer's accuracy in explaining the main idea of the story.

\section{Poetic colouring of detective stories}

Any detective story is mostly recognized as a very popular and a good reading matter. The process of reading and a reading understood as a book to read, might be defined as a figure that identifies a kind of the virtual reception method, which is characteristics for the stylistic form of detective stories.

A special character of detective stories might be observed on the pragmatic level, which means that this special genre of literature should be considered not only by using a stable set of standards but rather as a certain reading project, the specificity which can be better understood by focusing on possible actions accomplished by readers in the name of resolving the importance attributed to the text.

In this context all formal indicators of a detective story which define the stylistic peculiarities such as: a mystery, an investigation, red herrings, and final resolving of a crime, might be described in a role of forming a criminal reading matter featured in stylistic specialization ${ }^{7}$. In this light poetic colouring perceived through a reading experience according to S. Fish might be seen as a kind of occurrence that happens to a reader ${ }^{8}$.

To take a closer look at the aspect of a reading experience through the prism of stylistic features it is worth considering a conversation between supporting protagonists Mr. and Mrs. Bantry from The Body in the Library of A. Christie.

A story takes place in Gossington Hall, an English property, and the investigation is conducting by Ms Marple. It is worth paying attention to seemingly trivial episode considering the plot, when Mrs. Bantry is trying to convince her husband that there is a dead body of a young woman in the library. That kind of picture is consciously exaggerated by the author, but

\footnotetext{
${ }^{7}$ Kermode F. Novel and Narrative [w : ] Poetics of the Murder : Detective Fiction and Literature Theory, 1983. URL: www.worldcat.org/title/poetics-of-murder-detective-fiction-and-literary-theory (retrieved Feb. 16, 2019)

${ }^{8}$ Fish S., 1983. Literatura $w$ czytelniku: stylistyka afektywna, from Pamiętnik Literacki : czasopismo kwartalne poświęcone historii i krytyce literatury polskiej 74/1, 263-304 (retrieved Feb. 16, 2019)
} 
in fact deprived of much importance indeed in relation to criminal intrigue. Actually it is a satirical stylistic miniature which illustrates relationships between Mr. and Mrs. Bantry and their life on the post-Victorian province.

Trying to explain that unobvious relation amid reading matter and discourse among Bantry's marriage in the bedroom, it is useful to look closer at their reaction on dramatic discovery made in a house. Starting from a response of the retired officer (Mr. Bantry) whose behavior is significant enough to be cited: You dreamed of, Dolly. It is from this criminal affair you read The Secret of the Broken Match. Remember? Lord Edgbaston finds a corps, beautiful blonde, on the carpet in front of the fireplace. In novels corps always lay in the library. In reality I have never seen like this ${ }^{9}$.

It might be debatable if that commonsense unbelief or rather related to it colonel's obstinacy is really psychologically reasoned. It is probable that that kind of analysis is meaningless because colonel's reaction is caused by logic of a text. This logic assumes that Sir Bantry could not come to terms with corpse presence because this requires his belief that it is only reason to define the reality.

This perception is not explorative indeed but through it a status of derivativeness of the detective story is called into a question by Sir Bantry. Interesting here is a fact of the topical stylistic element of detective stories which might be discovered exactly in above colonel Bantry's statement. Even middlingly a familiarized reader of that genre is convinced that in detective stories there are plenty of similar comments to colonel's one. For example, in Murder in Three Acts investigation is conducting by three protagonists. In another story by A. Christie The Mystery of the Blue Train Hercule Poirot offers Katharine Grey to solve a mystery collectively after he observed that she read a detective story.

Similarly the same stylistic element is adapted by contemporary authors of that genre such as J. Alex or M. Grimes and P.D. James. In Original Sin by the latest one of scene takes place in London Club of Deceased which gathered law and criminalistics professional members. Its part and important scenario for story's intrigue is a description of the library where first editions of E.A. Poe's, W. Collins's and A.C. Doyle's were put on the very low shelve in the way to show everyone a primacy of the reality over the fiction. Nevertheless these measures might be seen as useless in detective story's convention and stylistic but also could invite to a deeper consideration about their functions.

That auto thematic stylistic element is considered also by J. Culler who the meaning of mentioned before Murder in Library's conversation

\footnotetext{
${ }^{9}$ Christie A., 2009. Noc w bibliotece. Wrocław. ISBN 9788324592265. P. 7.
} 
understood as Christie's strategy to induce the reader that the detective story is free from any genre confines and structural restrictions ${ }^{10}$.

The novelty in Culler's interpretation is that this convention might be useful to critic the detective fiction and is a base to read properly the creation process of that literature genre. He also states that in the detective fiction stylistic elements are also kind of dramatic irony and do not lead the reader to confidence that go beyond genre convention. In his opinion this convention as a form of genre specification become final to detective story's game rules. Culler also states that in Murder in Library a literary text uncovers an awareness of its affectation and conventionality to encourage the reader to observe reality from different point of view.

Culler claims also when reading any literary text presented events in the first place are compared with real images so it might be said that the initial stylistic interpretation is made by the reader. If fictional world should be qualified as real, elimination or justification potential disturbing poetic colouring always is needed, for example an ugly corpse of a young woman found by a servant in a library.

According to Culler a stylistic convention in detective stories is useful to cope with such disturbing elements to underline normal reader's reaction which might be observed in confrontation with going beyond fine lines of incident. So when colonel Bantry claims that corpse is usually found in library in detective stories, he points out that his world is under different rules and for readers it might be a sufficient alibi to easily agree with detective fiction mystification.

This kind of argumentation is crucial to recognize an ironic aspect of that situation and could be connected with good-time purpose of detective stories. Irony might be observed at three levels: a level of detective story which was read by Mr. an Mrs. Bantry, a level of their allegedly realistic world, and a level of the reader's Murder in the Library reality. A victim of such outlined situation, next to a corpse of a young woman (exactly the same as in detective stories which was noticed by colonel's wife with sarcastic tone), is also Mr. Bantry. He is right of course saying that in detective stories corpses are usually found in libraries, but verbalizing this he falls into a trap, because there is a corpse in his library as well. It might be assumed that lack of colonel's awareness that he is a fictional person too is a source of the reader's humor indeed.

By the way, the detective story as a literary genre from the very beginning was situated in mimetic and realistic fiction which is seen in genre rules formulated with more or less distance when some trickeries are

${ }^{10}$ Culler J., 1977. Konwencja i oswojenie [in : ] Znak - styl - konwencja. Warszawa. ISBN 978-83-7455-401-5. Pp. 173-176. 
banned. Nevertheless the claim that detective stories have a mimetic character might be a source of controversy. It is worth adding here about E. Wilson who alleged A. Christie that she pursued the elimination of human element implementing a kind of tasteless parody of people and lack of mere existence of characters ${ }^{11}$. Admittedly even detective story's writers of Golden Age were convinced that this genre of literature had infinitesimal derivative influence.

It might be introduced by a statement that the detective story is considered as a realistic story under specific conditions. According to M. Głowiński poetic colouring of detective story is reflected in genre convention through agreement between the reader and the author to believe in such unbelievable incident as a crime in Gosstington Hall.

That compromising of a detective story's poetic colouring might blur whole scene. Identifying the detective story as a one of realistic fiction is not sufficient to explain specific stylistic features of that genre. It is that because the reader is treating the detective story as a matter of major part of totality, so it is analyzed as the entirety, paying less attention to its distinctive features.

Above general comment is still actual even for researchers noticing fundamental differences between the detective story and a realistic discourse, but strongly underlining separate character of detective story's rules. It is worth adding here views of $\mathrm{R}$. Caillois who points out that detective stories try to explain unexplained. This French critic and sociologist understands that the reader is coping with nature's laws, probability, and common sense. Based on his opinions hence comes a value of that literary genre and it depends on starting point, which should be an insult for a mind and experience, then from more or less probable technique in which intellect and experience will be satisfied and respected ${ }^{12}$.

Unquestionably a realistic discourse is brought to the forefront here (probability, common sense, experience) but in Caillois's dilatation illusion is marginalized, which is then important for the reader. That illusion is essential because the fictional world in detective stories is presented in perlocutionary style so the reader is willing to believe in it. Having regard to this aspect Caillois is skeptic about the detective story's mission on that field, nevertheless it should be noted by the readers to rust in capacity of detective's power to reveal a criminal.

For Caillois the main stylistic element of the detective story is to explain unexplained and to reach a denegation of what is impossible for the

\footnotetext{
${ }^{11}$ Wilson E., 1973. Dlaczego kryminaty sa poczytne [w : ] Szkice. Warszawa. ISBN 83-07-01099-3. P. 180.

${ }^{12}$ Caillois R., 1967. Powieść kryminalna. Warszawa. ISBN 978-83-941843-3-9. P. 181.
} 
reader. Except that from the reader's point of view that situation is different than in normal realistic narration where probability between fiction and perception of a receiver is not a subject of realistic discourse. Meanwhile in the detective story an emphasis is laid on extraordinary circumstances of a crime and indirectly on a problem of realistic conditions of a story.

The novelty is Mr. Bantry's protest against the presence of a dead body in his library only potentially indicates that the matter under investigation is in fact not only a question about an identity of a perpetrator, but moreover a character of the story's reality. It might be suggested that a criminal mystery and some eccentric ideas connected with it are only testing of realistic discourse boundaries.

The novelty of this genre is also that a criminal topos of a locked room where a crime was committed might be locked not only for protagonists but for the readers as well. Helplessness of the police and witnesses is at the same time helplessness of the potential reader. It worth adding that a figure of a locked room is applied for the first time by E.A. Poe in The Murders in the Rue Morgue. Interesting here is the fact that grisly circumstances of a murder of two women in Parisian apartment are described in a press coverage. It might be suggested that through this stylistic device the externalization of reality is presented in way to expose the bare facts.

Using a press code by citing a text of articles about double murder the writer is creating a receivable situation which forcing the reader to follow the narrator and his friend detective A. Dupin investigation. Relation quoted from a crime scene provokes the reader to interpret events as an inscrutable mystery. This experience is characteristic because through it a confrontation between contrary energies such as reference in a press discourse and weirdness of a crime is possible. Locked doors in Parisian apartment are stylistic symbols of that confrontation because the reader is emotionally involved in a story through two acts of interpretation: the narrator's and press articles' interpretation.

An interpretation process is entangled in a reading matter and this fact might be translated into potential relation between the reader and a reading text. That process is connected with creating aspect of mimetic fiction and the base of imaginative ground of imitation level is not a world as an object but a reading matter itself. In this regard a fictional narration is shown as a representation of interpretation experience which suggests the reality boundaries.

Referring to above a cognitive interpretation is exposed in poetic colouring of the detective story and anti-illusion character is described by 
mentioned Caillois. He claims that in it, the main current ludic elements are exposed. Caillois also admits that a pleasure from reading the detective story is not the same as a pleasure from hearing a story. In his opinion it is rather a pleasure from watching a prestidigitator who immediately reveals a secret of his tricks. Even for E. Wilson characteristic poetic element of the detective story recalls a conjuring trick reliant on distracting the reader's attention using meaningless and incapable gestures.

As it can be seen both writers invoke to illusion and manipulation tricks, and refuse the detective story realistic features in fact. Both also claim that the detective story has an artistic value. The novelty of this genre is that both finally underestimate a ludic destiny and see it as deviation from a real exposition. Although it is worth adding that it is Caillois who shows better understanding of the detective story's genre specific by underlining vanishing tricks. He argues that the reader expects revealing of a crime from the conclusion of a story as well. It means that the narrator of a story should in some ways identify with a mechanism of narration trap prepared for the reader.

That role plays numerous functions in detective stories' auto thematic comments. Similar function is assigned to intertextual allusions to other detective stories or detective protagonists which both should dispose the reader to active involvement in decryption of detective story's criminal code.

A common denominator of these actions is a general conclusion that a reading experience is crucial in every detective story's investigation. According to $\mathrm{P}$. Huhn there is the analogy between hidden story of fictional murder and a story of reading and story of investigation as a detective's interpretation. Another researcher of detective fiction C. Malmgren combines analogy between detective's actions and the reader's pleasure from a reading matter.

Both cited researchers are in close relation to stylistic character of detective story. Seemingly they are in a distance from a naive definition of detective fiction as similar to performance but in the same time indirectly allude to that definition. If there is a parallel between doings or attitude of detective and the reader's status so that metaphoric figure is only a mask of illusive mechanism of identity with fictional protagonist.

It might be said that the poetic colouring of the detective story are helpful in reading process so the reader can better understand detective's actions. The novelty claims that the stylistic peculiarities are presented through the process of reading detective stories and they are hidden in revealing the truth, making impossible possible, and creating possible scenarios in coping with evil. 


\section{Methods of writing detective stories}

Writing the detective story requires a reasonable combination of talent and organization where one cannot exist without the other. Organizational skills are something so natural for writers that they do not realize it. Authors prepare a chapter plan to make easier writing detective stories. The potential reader often assesses the book on its first page. Despite the interesting title, eye-catching cover and advertising note full of words such as dynamic, breathtaking, fascinating or similar words which are applied to the promotion of this type of literature, if the first page is not sufficiently interesting the reader does not want to read it at all.

This does not mean that each detective story begins with shooting or blowing up a luxury car, however, the authors make sure that their story will have the same tonality as the whole. For example, the characters who are supposed to live in constant fear in the first scene often feel uncomfortable as a result of an accidental incident, which gives the reader a taste of what awaits him later. The authors of detective stories do not start their books from a funny event but try to introduce the atmosphere of the genre from the beginning. The first paragraphs present the rest of the story.

The methods of writing detective stories are in a proper tonality which is very essential issue. Often, if the author is not sure about the right tonality of the prepared story, he can ask himself: what kind of emotions might arouse in the reader through a story? Regardless of the answer, the author should try to make a story arousing similar feelings among the readers. Description of whether the situation that excites or worries the writer is likely to work in the same way in relation to others. The author would like the reader to experience the final climax and also climactic points during the narrative if they are.

Another important element of writing the detective story is a pace of describing the story. Formerly the first scene of the story contained an introduction regarding characters and places. Now the reader expects something to happen right away that is why writers try to make the first scene as a rudiment of a story and a sample of a book's atmosphere. In the first scene authors usually present at least one protagonist and impalement a charge of uncertainty to make the readers to devours next page till the end of the story.

In the first chapter there is a space dedicated to determining the pace of the entire story. The author trying to assess whether the beginning of his story is good can ask himself the following questions: whether on the front page of the typescript it was able to show the conflict which will be at the heart of the story; whether he informed the reader that it will be a story about danger, mystery; whether the place of action has been sufficiently 
presented and finally whether the descriptions are consistent with the themes of the book and the first scene.

The secret in writing the detective story is how the first page looks. Authors often claim that it is good when it is not an uninterrupted text string with two or three variable length paragraphs. Writers often implement a brilliant phrase to attract the readers' attention.

Undoubtedly, a valuable first paragraph sometimes called an introduction, should be absorbing the reader's attention. It also should give an idea of a subject area and the pace of a story. For example in Rebecca by D. du Maurier there is a natural smooth phrase: Last night I dreamt I went to Manderley again ${ }^{13}$.

This beginning so fluently fits into the whole story that it seems almost impossible to start with another sentence. It might be that $\mathrm{D}$. du Maurier devised it later, after writing some text, but unquestionably it applies to the story very much.

Nothing intrigues the reader as a bit of a mystery. In famous detective story Malice Aforethought by F. Iles (in fact his true name was A.B. Cox) there is a shocking news that Dr Bickleigh decided to kill his wife and to reach a goal he gathers needed information: Only a few weeks after he decided to kill his wife certain steps had been taken by Dr. Bickleigh in this direction. ${ }^{14}$ After such words the readers want to know what happened next. And that is in fact an essence of detective fiction: intriguing and keeping at tension the reader. Again and again the reader's curiosity is planted by mysteries and surprising elements.

It is worth mentioning here about a famous detective story The Hatter's Ghost by G. Simenon where the reader has an opportunity to be involved in incredible mood of a mystery fiction from the very beginning: It was the third of December and it was still raining. The black three with a slightly too prominent tummy cut off from the whiteness of the calendar attached to the counter in front of the partition of a cold oak separating the shop window from the shop itself. Exactly before twenty days, because it happened on November 13 - another stocky three on the calendar - at the church of the Savior a few steps from the channel the first old woman was murdered $^{15}$. G. Simenon used simple language to describe a story and that was his power indeed. He did not apply sophisticated sentences but only pronounced image in a blackest colors of a simple thing after which there was a shocking information about a murder. In these three sentences Simenon provides a disturbing tonality of further story.

\footnotetext{
${ }^{13}$ Maurier du D., Rebecca. URL: www.e4thai.com /Rebecca.pdf (retrieved Feb. 18, 2019)

${ }^{14}$ Iles F. Malice Aforethought. URL: www.e4thai.com/MaliceAforethought (retrieved Feb. 18, 2019)

${ }^{15}$ Simenon G. The Hatter's Ghost. URL: www.googlebooks.com (retrieved Feb. 18, 2019)
} 
As a contrary another detective story might be presented. M. Millar's The Soft Talkers where there is an intriguing understatement dialog between protagonists: Ron Galloway's wife saw her husband for the last time one Saturday evening in mid-April. He seemed to be in a good mood then - said Ester Galloway. - If he was going to do something, he planned something. I mean more than a fishing trip. He never liked fishing, he was morbidly afraid of water $^{16}$. In that passage there is also a puzzling element: why Ron Galloway was thinking about a fishing trip while he was afraid of water?

In The Talented Mr. Ripley P. Highsmith created also a mood of anxiety which is in the whole book: Tom looked back and saw a man coming out of Green Cage, heading towards him. He accelerated his step. He had no doubt that the man was following him. Tom spotted him five minutes earlier at the table when he looked at him as if he was not sure about something. For Tom he looked so clearly that he finished a drink in a hurry, paid and left ${ }^{17}$.

L. Dieghton starts his detective story Berlin Game from a dialogue which from the beginning combines personal and political threads: - How long have we been sitting here? - I said. I picked up the field glasses and studied the bored young American soldier in his glass-sided box. - Nearly a quarter of a century, - said Werner Volkmann. His arms were resting on the steering wheel and his head was slumped on them. That GI (soldier) wasn't even born when we first sat here waiting for the dogs to bark. Barking dogs, in their compound behind the remains of the Hotel Adlon, were usually the first sign of something happening on the other side. The dogs sensed any unusual happenings long before the handlers came to get them. That's why we kept the windows open; that's why we were frozen nearly to death. - That American soldier wasn't born, the spy thriller he's reading wasn't written, and we both thought the Wall would be demolished within a few days. We were stupid kids but it was better then, wasn't it, Bernie - It's always better when you're young, Werner, - I said. This side of Checkpoint Charlie had not changed. There never was much there; just one small hut and some signs warning you about leaving the Western Sector. But the East German side had grown far more elaborate. Walls and fences, gates and barriers, endless white lines to mark out the traffic lanes. Most recently they'd built a huge walled compound where the tourist buses were searched and tapped, and scrutinized by gloomy men who pushed wheeled mirrors under every vehicle lest one of their fellow countrymen was clinging there ${ }^{18}$.

\footnotetext{
${ }^{16}$ Millar M. The Soft Talkers. URL: www.googlebooks.com (retrieved Feb. 18, 2019)

${ }^{17}$ Highsmith P. The Talented Mr. Ripley. URL: www.googlebooks.com (retrieved Feb. 20, 2019)

${ }^{18}$ Deighton L. Berlin Game. URL: www.literatyresave2.files.wordpress.com (retrieved Feb. 20, 2019)
} 
S. Grafton's $C$ is for Corps is staring from a few dynamic sentences written from heroin's perspective: I met Bobby Callahan on that Monday. He was already dead on Thursday. He was convinced that someone wanted to kill him and it turned out that he was right. None of us realized it early enough to save him. I worked for the first time for someone dead and I hope for the last time. This report is for him, no matter what its value is ${ }^{19}$.

P.D. James is shocking the readers by presenting in the first chapter a corpse and mystery in Unnatural Causes: The corpse without hands lay in the bottom of a small sailing dinghy drifting just within sight of the Suffolk Coast. It was the body of a middle-aged man, a dapper little cadaver, its shroud a dark pin-striped suit which fitted the narrow body as elegantly in death as it had in life. The hand-made shoes sill gleamed except for some scuffing of the tope caps, the silk tie was knotted under the prominent Adam's apple. He had dressed with careful orthodoxy for the town, this hapless voyager; not for this lonely sea; nor for his death ${ }^{20}$.

R. Rendall in A Judgment in Stone also starts with horrifying beginning: Eunice Parchman murdered the Coverdale family because she could not read or write. There was no significant motive and no premeditation; they were not looted here, neither money nor valuables. As a result of this crime, not only family and local residents learned about the disability of Eunice but the whole country. With this deed she defeated herself, though she had been subconsciously aware of the sorrow that it would be so, that she would gain nothing. Yet, unlike her insane companion and partner, she did not show signs of madness. It was frighteningly normal, like a prehistoric creature who takes on the form of a woman from the twentieth century ${ }^{21}$.

The presented examples shows that the authors of the detective stories try to interest the reader from the very beginning by implementing shocking or even stunning scenes. It might be assumed that writers often use checking questions to make a story interesting such as: if first paragraphs have the same tonality as the rest of a story, if there is a stirring of a conflict or mystery, if the setting is properly located, if there are sufficient dialogues in a story.

\section{Manipulation of the reader's attention in A. Christie's detective stories}

When the reader's attention is manipulated for plot construction reasons it might be used the foreground strategy by the author to redirect

\footnotetext{
${ }^{19}$ Grafton S. C is for Corps.URL: www.googlebooks.com (retrieved Feb. 20, 2019)

${ }^{20}$ James P.D. Unnatural Causes. URL: www.googlebooks.com (retrieved Feb. 20, 2019)

${ }^{21}$ Rendell R. A Judgment in Stone. URL: www.googlebooks.com (retrieved Feb. 20, 2019)
} 
the readers' attention. The term foreground was first used in the Garvin's stylistics of translation in 1964 and in the work of Havránek in 1964. It generally refers to cases where the language is sufficiently different to attract attention and through it encourage interpretation of additional meaning 22 .

In detective fiction there is distinction between handling of a plot significant and a plot insignificant items. Plot is understood here as solving a mystery, such as a suspect death, and this definition is used simply to facilitate exposure, how clearly other aspects of the plot may exist, with the exception of the main puzzle. Many plot significant items are important for e.g. a solution, an evidence of how the suspected death took place, whereas plot insignificant items do not have such importance.

To better understanding the key poetic colouring that can be found in detective stories it is worth explaining also the term burying. In literature some items might be brought into mentioned above the foreground, then other items might be left in the background. The notion of background is little studied in Stylistics, but has been of interest to linguists and psychologists $^{23}$.

As it was mentioned stylisticians are not interested in background because placing information there is not usually viewed as an important strategic choice. Although, for plot purposes, deliberately burying information in the background of a text is highly strategic, and by burying, it is meant that an item is placed in the background with the intention that it should not be easily found ${ }^{24}$.

The key stylistic strategies of using the techniques for foregrounding and burying strategies might be presented:

- Strategy 1: At the pre-solution stage - foreground plot insignificant items. It might be a classic "red herring" (false clue) of detective fiction. An item may be seen as significant at the time of presentation, but later it occurs that there was a false trace and, the item turns out to be insignificant at the solution stage.

To explore that strategy, it is worth demonstrating how A. Christie utilizes it in detective stories. She often presented a list of items in which one or more had plot significance and implemented trick to use foregrounding to lead the reader the wrong path, but in a way that allowed to interpret in a subsequent way of the scene at the solution stage. A good example might be Murder in the Mews where list of items on a writingbureau occurs when $\mathrm{H}$. Poirot and Inspector Japp are in the process of

\footnotetext{
${ }^{22}$ Strtegies in writing. URL: www.eprints.gla.ac.uk/70404/1/70404.pdf (retrieved Feb. 22, 2019)

${ }^{23}$ Strtegies in writing. URL: www.eprints.gla.ac.uk/70404/1/70404.pdf (retrieved Feb. 22, 2019)

${ }^{24}$ Strtegies in writing. URL: www.eprints.gla.ac.uk/70404/1/70404.pdf (retrieved Feb. 22, 2019)
} 
examining a room in a house where a dead woman was found: Poirot strayed across to the writing-bureau. [...] There was a somewhat massive silver inkstand in the centre, in front of it a handsome green lacquer blotter. To the left of the blotter was an emerald glass pen-tray containing a silver penholder - a stick of green sealing-wax, a pencil and two stamps. On the right of the blotter was a movable calendar giving the day of the week, date and month. There was also a little glass jar of shot and standing in it a flamboyant green quill pen. Poirot seemed interested in the pen. He took it out and looked at it but the quill was innocent of ink. It was clearly a decoration - nothing more. The silver penholder with the ink-stained nib was the one in use. His eyes strayed to the calendar. "Tuesday, November fifth," said Japp. "Yesterday. That's all correct." Poirot and Japp discuss the time of death with the forensic expert. Poirot had turned back the cover of the blotter. "Good idea," said Japp. "But no luck." The blotter showed an innocent white sheet of blotting-paper. Poirot turned over the leaves but they were all the same. He turned his attention to the waste-paper basket. [He finds various old circulars and standard letters. "Nothing there," said Japp. [...] Poirot still seemed fascinated by the writing-bureau and its appointments. He left the room, but at the door his eyes went back once more to the flaunting emerald quill pen ${ }^{25}$.

The description of a pen which is flamboyant green at first and then, at the end of the extract, "flaunting" gives this item apparently narrativeworld meaningfulness. The attention of a character who could control the way information is presented, and even could control the attention of the reader. In the second paragraph, the reader is told that Poirot seemed interested in the quill pen and there is an information that he examines it. At the end of this example the reader learns that he still seemed fascinated by the writing-bureau but the one item occurred especially interested for Poirot - the quill pen. In fact a quill pen is a red herring (a false clue). At the stage of dissolution, interest in the quill pen will have to be rejected when the real solution is revealed and Christie allows herself some room for maneuver. When she mentioned that Poirot seemed interested and fascinated, she did not give a full narrative commitment to these descriptions. Either the narrator is mistaken about Poirot's interest, or, if the narrator is right, Poirot is interested in the red herring. Theoretically, this may not reflect well on his detective abilities, but in practice there are potential difficulties in building the plot.

- Strategy 2: At the pre-solution stage - bury plot significant items.

Detective authors must implement items that eventually contribute to the solution. If they did not introduce them at all, they might be accused of

\footnotetext{
${ }^{25}$ Christie A., 1964. Murder in the Mews. London. Fontana. ISBN 9780062073990. pp. 11-13.
} 
impure doings. That skill regards mentioning these items without paying attention to them as not being important or associated with the solution. In above example A. Christie used the attention of the characters to stop possible interest of others items: To the left of the blotter was an emerald glass pen-tray containing a silver penholder-a stick of green sealing-wax, a pencil and two stamps. On the right of the blotter was a movable calendar $^{26}$.

When the pen tray is mentioned the description moves to another item: calendar. Then the author mentioned about silver penholder and it is followed by Poirot's eyes straying to the calendar. His attention again moved on the bottler and the waste-paper basket seemed to have no interest to Japp's because he said: "Nothing there". Actually, what eventually turned out to be interesting at the solution stage was, firstly, the lack of any used blotting-paper on the blotter, and, secondly, the relative position of the items on the writing table. These factors turned out to be significant because they provided evidence for death which was a suicide, not a murder (one of the characters was framed for murder).

- Strategy 3: At the solution stage - foreground plot significant details that were previously buried and make the solution seems to be credible.

That strategy was used by A. Christie when Poirot revealed the solution by employing foregrounding to emphasize some aspects which were not been emphasized earlier: And now I come to something really interesting - I come, my friends, to the writing-bureau. [...] That was really very odd - very remarkable! For two reasons. The first reason was that something was missing from that writing-table. [...] A sheet of blotting-paper, mademoiselle. The blotting-book had on top a clean, untouched piece of blotting-paper. [...] it was not in the waste-paper basket. [...] A curious little problem. I looked everywhere, in the wastepaper baskets, in the dustbin, but I could not find a sheet of used blottingpaper - and that seemed to me very important. [...] But there was a second curious point about the writing-table. Perhaps, Japp, you remember roughly the arrangement of it? Blotter and inkstand in the centre, pen tray to the left, calendar and quill pen to the right. Eh bien? You do not see? The quill pen, remember, I examined, it was for show only - it had not been used. Ah! still you do not see? I will say it again. Blotter in the centre pen tray to the left - to the left, Japp. But is it not usual to find a pen tray on the right, convenient to the right hand? "Ah, now it comes to you, does it not? The pen tray on the left [... (Poirot here turns to speak to the accused woman) ...] you find your friend there lying dead with the pistol

\footnotetext{
${ }^{26}$ Christie A., 1964. Murder in the Mews..., op. cit., pp. 11-13.
} 
clasped in her hand - the left hand, naturally, since she is left-handed and therefore, too, the bullet has entered on the left side of the head. [...] You take the pistol, wipe it and place it in the right hand"27.

The foregrounding does not only provide re-framing of the information, but it also serves to suggest the detective's authority and alleged obviousness hence the credibility of the solution. Many initial statements such as: really interesting, very strange, very unusual, are highly evaluative, and this evaluation was continued throughout the Poirot's revelation by saying: Curious small problem, which seemed to me very important, second interesting point. In addition, Poirot used the questions to describe Japp's process of discovery as if there was no other possible option, and thus also conducting this discovery process of the readers: Eh bien? Do not you see?, Ah, you still do not see?, Ah, now it comes to you, right?

In above cited passage there is heavy repetition: pen tray on the left, left, pen tray on the left, left hand, she is left-handed; and Poirot even says: I will say it again to emphasize this repetition. Adverbs like: naturally and because also emphasize the alleged inevitability of this explanation. Negative arrangements about the blotter and waste bin were re-framed again as the key findings because they were considered to be significant when these discoveries were negative. This example is similar to the observation of Sherlock Holmes about the curious incident of the dog in the night in Silver Blaze, where the curious incident was that the dog did nothing. It should be remembered that in detective stories the absence of the item might be more relevant than the evidence.

Above described strategies reflect the core aspects of stylistic issues of detective stories, but also apply to their plot construction in general. The authors of detective fiction with surprise endings use foregrounding and burying to carefully direct readers to control their attention and thereby to achieve stylistic manipulation.

\section{CONCLUSIONS}

Detective stories are well-written in terms of language and stylistics demands. The novelty is that they are stylistically valuable, because the authors attach huge importance to the formal side of the text. Even though in that stories there is much level of profanity or brutality, this is rather due to the specifics of the genre.

By analyzing texts of detective stories in terms of purposefulness, usefulness and appropriateness of linguistic means used in it, it might be

${ }^{27}$ Christie A., 1964. Murder in the Mews...., op. cit., P. 51. 
assumed that those works appeal to demanding readers who reach for it to read something intelligently written.

In view that stylistics uses all sections of the language science for its needs: phonetics to be able to study the textual value of the text; morphology and word formation, which may be helpful, for example, when recognizing the inflected forms or neologisms used by the author; syntax, became the construction of sentences also affects the stylistic value of the text; semantics, which helps to assess the validity of the vocabulary used, detective stories' style also rely on those elements.

\section{SUMMARY}

In the article poetic colouring through the prism of methods of reading detective story are presented. The description of the process of reading detective stories is depicted in the light of using not only a stable set of standard methods but also a certain reading project to understand the described actions and being involved to solve a mystery.

In the research there is a presentation of methods of wiring detective stories. The author of detective story tries to interest readers from the first page by introducing an interesting element. It might be unexpected crime, an odd conversation, an intrigue description of characters. It is highlighted that the essential elements of good style are: fluency of language, correctness in using words, grammatical accuracy, and ease in narration of the story.

In the article the presentation of three strategies is viewed used by A. Christie in managing to draw the readers' attention in the light of stylistic strategies. It is emphasized that at the pre-solution stage false clues might be significant in uncovering the truth, might bury plot significant items or plot significant items that were previously buried can make the solution reliable.

\section{REFERENCES}

1. Brophy B. Detective Fiction: A Modern Myth of Violence? The Hudson Review. Vol. 18, No. 1. 1965.

2. Christie A.Murder on The Orient Express. Wydawnictwo Hachette, 2000.

3. Kermode F Novel and Narrative [in:] Poetics of the Murder: Detective Fiction and Literature Theory. 1983. retrieved from: www.worldcat.org/title/poetics-of-murder-detective-fiction-and-literarytheory

4. Preus A. Historical Dictionary of Ancient Greek Philosophy. Lanham, Maryland, Toronto, Oxford. The Scarecrow Press Inc. 2007. 
5. Symons J. The Bloody Murder: From The Detective Story to Crime Novel. Mysterious Press, New York. 1993.

6. Encyclopedia Britannica. www.britannica.com/style in literature

7.Zizek S. Logika powieści detektywistycznej, retrieved from: Pamiętnik Literacki: czasopismo kwartalne poświęcone historii i krytyce literatury polskiej 81/3. 1990.

\section{Information about the author:}

Babelyuk O. A., Doctor of Philology,

Professor at the Department of Foreign Languages and Translation, Lviv State University of Life Safety 35, Kleparivska str., Lviv, 79000, Ukraine 